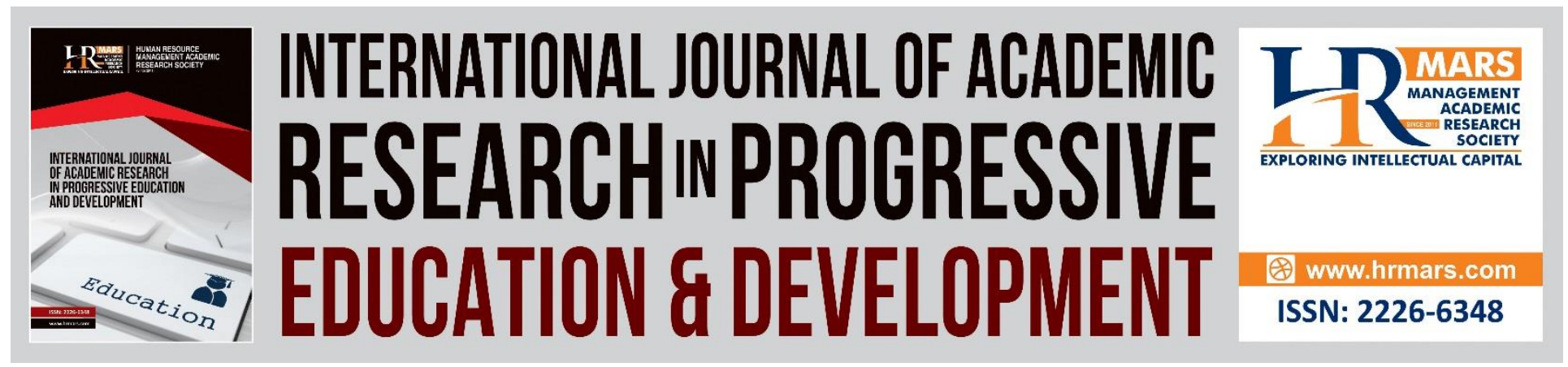

\title{
Using E-Learning in English Language Teaching: A Systematic Review
}

\section{Keranjit Kaur A/P Hari Singh, Melor Md Yunus}

To Link this Article: http://dx.doi.org/10.6007/IJARPED/v10-i1/8338
DOI:10.6007/IJARPED/v10-i1/8338

Received: 03 December 2020, Revised: 01 January 2021, Accepted: 17 January 2021

Published Online: 14 February 2021

In-Text Citation: (Singh \& Yunus, 2021)

To Cite this Article: Singh, K. K. A. H., \& Yunus, M. M. (2021). Using E-Learning in English Language Teaching: A Systematic Review. International Journal of Academic Research in Progressive Education and Development, 10(1), 51-62.

Copyright: (C) 2021 The Author(s)

Published by Human Resource Management Academic Research Society (www.hrmars.com)

This article is published under the Creative Commons Attribution (CC BY 4.0) license. Anyone may reproduce, distribute, translate and create derivative works of this article (for both commercial and non-commercial purposes), subject to full attribution to the original publication and authors. The full terms of this license may be seen

at: $\underline{\text { http://creativecommons.org/licences/by/4.0/legalcode }}$

\section{Vol. 10(1) 2021, Pg. 51 - 62}

\section{http://hrmars.com/index.php/pages/detail/IJARPED}

JOURNAL HOMEPAGE

Full Terms \& Conditions of access and use can be found at http://hrmars.com/index.php/pages/detail/publication-ethics 


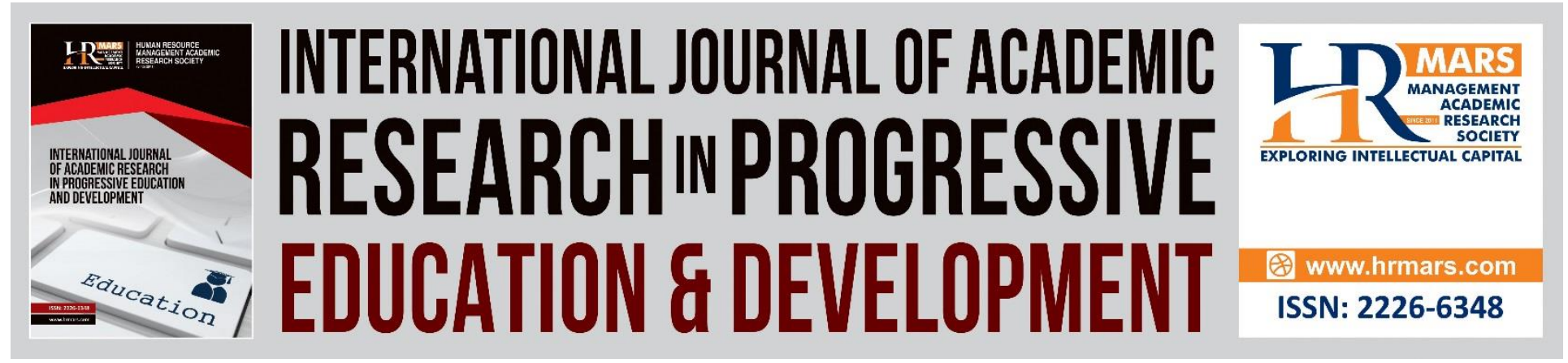

\title{
Using E-Learning in English Language Teaching: A Systematic Review
}

\author{
Keranjit Kaur A/P Hari Singh, Melor Md Yunus \\ Faculty of Education, Universiti Kebangsaan Malaysia (UKM), Bangi, Malaysia \\ Email: kirangal14@gmail.com,melor@ukm.edu.my
}

\begin{abstract}
The growth of education in Malaysia should be in line with the current development of Information and Communication Technology (ICT), as teaching methods have shifted from traditional teacher-centered to student-centered, as well as the skills required for a quality teacher are altering from time to time. However, English language teachers are not driven which will undesirably affect students' performance despite all the efforts that have been made to improve the development of education. Therefore, the paper aims to present a systematic review of appropriate published studies to determine ESL teachers' attitudes towards the use of elearning and identify issues faced by ESL teachers in the use of e-learning. This review synthesized findings from 22 journal articles published from the year 2016-2020 from Google Scholar and Eric accordingly. Overall, the results showed that there is positive reinforcement with the proper usage and incorporation of e-learning in the teaching of the English language as that will aid the teachers to perform better and create the quality level of students.
\end{abstract}

Keywords: E-Learning, Attitudes, Issues, Education, English Language

\section{Introduction}

The English language tends to have an influential force on the education aspect as it is continuously growing to explore innovative methods to teach the language effectively and efficiently to form a productive learning environment (Paul, 2017). It was supported by a study conducted by Lie (2017) discovered that the outdated way of teaching English in and out of the classroom was recognized as discouraging and demotivating to the students. Also, the Education Blueprint (2013-2025) plays a major role in developing the future of a child's education from preschool to university level with equal prospects to proper schooling as well as prioritize the teaching of the English language as a second language. Gani, Fajrina \& Hanifa (2015) Other scholars (Rochanahasadin et al., 2019) have proposed that teachers should upsurge the interest of students in learning English based on various methods to produce active learning and maintain student engagement in the lesson. 
Swift development in e-learning has taken place as it holds an all-embracing range of technologies which includes the increase of computers, Internet, and social networking sites regarding the variety of ways in teaching and learning English (Nadzrah, 2007). Progression of technology has boundless impacts on the students' life in and out of school as it supports to stimulate and increase their attention span during the lesson. It is enormously becoming one of the imaginative and modern learning tools in the classroom. Yunus et al. (2013) agreed that there has been snowballing attention and need in using computers and the Internet to boost teaching and learning in the education field. This is because visuals or audios tend to entice students' attention quickly as each one of them has a particular learning ability. For example, e-learning can be accessible in various ways such as in the form of texts, images, tables, graphs, or even multimedia which can make the class more thought-provoking and energetic, as well as one, feel more motivated and determined to learn a lesson actively (Yunus, et al., 2013).

However, English language teachers are conscious of the worldwide challenges especially in preparing themselves to achieve the goal of the Malaysian Education Blueprint (MEB). Qualified and accountable teachers do not only show their competence in the subject area but also encourage their students in terms of displaying sociability, confidence and producing a favorable learning environment (Yunus \& Suliman, 2014). A motivated and committed teacher has the opportunity to influence the student significantly in building a global view that rests on a faith commitment. The aptitude and assurance of teachers have been widely acknowledged to be a significant factor in learning outcomes. (Dash \& Barman, 2016). Up till now, there is a lack of studies on a systematic review of using e-learning in English language teaching as the reviews could be benefited by the education community (Noesgaard \& Orngreen, 2015).

Moreover, the outbreak of Covid-19 which has shaken the education community globally this year has impacted every aspect of life, that includes teaching and learning. Educators and students at all levels in education are still grappling to adapt to new ways of remote teaching and learning via the internet. Normal ways and routines used previously are not applicable in this pandemic which we have yet the see the end of, thus teachers and students adjust to new norms. Therefore, it is important to identify the issues and attitudes of teachers as a way of addressing educational issues. This paper is aimed to answer two research questions: a) What are ESL teachers' attitudes towards the use of E-Learning and b) What are issues faced by ESL teachers in the use of E-Learning? as a guide in selecting the suitable articles to review accurately.

\section{Literature Review}

\section{E-Learning in Teaching of English Language}

The rapid evolution of technology has greatly changed every aspect of life including language pedagogy, language learning, and language use. In research by Miangah and Nezarat, (2012), they believed that e-learning plays as an important motivator that is helpful for teachers and students in the classroom. Licorish et al. (2017) agreed, that students will be able to engage in the lesson quickly as they explain the pictures by using the appropriate form of the structures. Elearning also has a positive impact on students' learning as it makes them more engaged in the lesson which resulted in retaining more information. This was also supported by Fitriah (2018) that e-learning promotes the improvement of the memorizing concepts and better performance in terms of results. 
ESL teachers as successful language learners should always be aware and open to experimenting with new skills as well as be creative with the teaching and learning of English in and out of the classroom as proposed by Maulidar, Gani \& Samad (2019). As an ESL teacher, one should always be occupied with proper knowledge and readiness to improvise the subject matter according to every students' ability and capacity based on e-learning as revealed by Hardan (2013). This will help students to be more self-assured and expressive when speaking a particular language, and also eliminate the fear of making mistakes as they will know the effectiveness of the skills by incorporating them in their daily lives. It is a significant aspect of education because effective teaching motivates teachers as well as aids students in learning and increasing academic performance (Hamid, Hassan \& Ismail, 2012).

Past studies proposed that e-learning could be measured by the influence of teachers on students' achievement. However, measuring a teacher's quality is a complex process as it involves teaching preparation and assurance (Darling-Hammond, 2000), experience and information (Goe, 2007), pedagogical skills and optimism as well as system and skills (Waxman et. al., 2003). Research on the use of e-learning tools in the classroom has shown that ICT makes a supportive and encouraging environment for the students to increase their basic skills in terms of quality and quantity (Pandey \& Mishra, 2016). The findings of the research were reinforced by Zorío (2018) who conducted a study on an effective online resource called Kahoot, an online game resembling a quiz that is very popularly used by teachers.

Overall, most of the students were involved during the lesson and used e-learning devices such as their computers and mobile phones which promotes their motivation towards learning English. Licorish et al., (2017) agreed, stating that students will be able to learn better and independently as they are being motivated continuously throughout the teaching process. Sharma (2018) claimed that e-learning has undeniably helped improve students' basic skills as it increases participation in classroom activities. The result of the study showed that the students picked up various strategies throughout the lesson such as memory, cognitive, compensation, metacognitive, affective, and social strategy to accomplish their goals with the help of e-learning.

Harris \& Rutledge (2007) have resolved that the forecasters of teacher quality and effectiveness are reasoning ability, character attributes, and educational background based on e-learning. It is also mentioned that teachers have to be dedicated and motivated towards the teaching process if they want to see improvement in the students' academic performance. Most of the schools, both primary and secondary have been restructuring the education methods and approaches to increase the teaching effectiveness that will enhance the English language teacher's motivation as depicted by Sikand \& Kauts (2016). In the 21st century, teachers are gearing towards adopting and adapting new teaching strategies and approaches to have a balance and positive learning environment through e-learning (Tehseen \& Hadi, 2015).

\section{Methodology}

A systematic review uses a specific search strategy to direct the inclusion and exclusion of studies in a study to deliver objective and detailed findings (Zakariaa, Maat \& Khalid, 2019). This is because a review is described as a research piece driven by an explicit and clear collection of methods and stages with replicable and updated potential. This paper is based on systematic analysis conducted on searched articles from databases which include Google Scholar and Eric 
from the year 2016-2020. The process of the literature search was done from April 2020 to June 2020. The purpose of the review is to determine ESL teachers' attitudes towards the use of elearning and identify ESL teachers' issues faced in the use of e-learning. Therefore, five steps proposed by Khan (2003) were used in this paper as this approach has helped to interpret, test, and critically synthesize complex concepts as shown in Figure 1 (Khan et al., 2003).

\section{Step 1: Framing Questions for A View}

Technological development has enabled e-learning to become a greater opportunity to expand learning to include not only the classroom but virtual learning as well. Therefore, this paper aims to determine ESL teachers' attitudes towards the use of e-learning and identify the issues faced by ESL teachers' in the use of e-learning, published from 2016 to 2020. The research questions are a) What are ESL teachers' attitudes towards the use of e-learning? and b) What are issues faced by ESL teachers' in the use of e-learning?

\section{Step 2: Identifying Relevant Work}

The second phase in a systematic review is identifying relevant work. In the initial study, all related papers are collected and this is followed by choosing the suitable articles based on the criteria for inclusion and exclusion. Thus, the search was limited to full-text articles and peer review journal articles to make better comparisons between sources to determine ESL teachers' attitudes towards the use of e-learning and identify issues faced by ESL teachers in the use of elearning (Teng, 2016). Two databases were used in this study, which was Google Scholar and Eric to ensure comprehensive data collection. As a result, the search using the keywords 'attitudes towards e-learning' and 'issues faced with e-learning' in the Google Scholar database resulted in 120 studies published from 2016 to 2020. Next, the search using the keywords 'attitudes towards e-learning' and 'issues faced with e-learning' in Eric database resulted in 100 studies published from 2016 to 2020. This totals up to 220 studies when added with both results from Google Scholar and Eric.

\section{Step 3: Assessing the Quality of Studies}

To ensure the quality of this review, as part of the systemic review process, the selection of the studies must be based on the framework criteria. The criteria for inclusion and exclusion were defined to identify articles that will be included or excluded from this study since only the ones that meet the criteria for inclusion and exclusion were selected in this study, as shown in Table 1. An appropriate research procedure comprised of six inclusion criteria and six exclusion criteria stated separately in Table 1 labeled as the key characteristics of the relevant articles selected to answer the research questions. In this review, 198 articles that did not meet the inclusion and exclusion criteria were removed, leaving 22 articles to be included in this study. 
Vol. 10, No. 1, 2021, E-ISSN: 2226-6348 @ 2021 HRMARS

Table 1: Inclusion and Exclusion Criteria

\begin{tabular}{|l|l|}
\hline Inclusion Criteria & Exclusion Criteria \\
\hline $\begin{array}{l}\text { Teaching the English language by using e- } \\
\text { learning }\end{array}$ & $\begin{array}{l}\text { Teaching the English language by not using } \\
\text { e-learning }\end{array}$ \\
\hline $\begin{array}{l}\text { Types of research methodology such as } \\
\text { quantitative, qualitative, and mixed-method }\end{array}$ & $\begin{array}{l}\text { Types of research methodology were not } \\
\text { accessed and evaluated. }\end{array}$ \\
\hline Participants from several levels of education & $\begin{array}{l}\text { Participants not from several levels of } \\
\text { education }\end{array}$ \\
\hline $\begin{array}{l}\text { To determine ESL teachers' attitudes } \\
\text { towards the use of e-learning and identify } \\
\text { ESL teachers' issues faced in the use of e- } \\
\text { learning }\end{array}$ & $\begin{array}{l}\text { To not determine ESL teachers' attitudes } \\
\text { towards the use of e-learning and identify } \\
\text { ESL teachers' issues faced in the use of e- } \\
\text { learning }\end{array}$ \\
\hline Original studies published in the journal & Other than journal articles \\
\hline Published between 2016 till 2020 & Not published between 2016 till 2020 \\
\hline
\end{tabular}

\section{Step 4: Summarising the Evidence}

Google Scholar was used as the first database in this study. The search using the keywords 'attitudes towards e-learning' and 'issues faced with e-learning' in articles published from 2016 to 2020 resulted in 120 results. The remaining articles were sorted into inclusion and exclusion criteria. 108 articles that did not meet the inclusion and exclusion criteria were removed because the author could not access the full text, leaving 12 articles to be included in this study. The second database used in this study was Eric. The search using the keywords 'attitudes towards elearning' and 'issues faced with e-learning' in articles published from 2016 to 2020 produced 100 results. The remaining articles were sorted into inclusion and exclusion criteria. 90 articles did not meet the inclusion and exclusion criteria thus were removed because the researcher did not have access to the full text, leaving 10 articles to be included in this study. Finally, only 22 articles were used in this study after all the process.

\section{Step 5: Interpreting the Findings}

In the fifth phase, the findings were interpreted using content analysis to analyze the data precisely. A total of 220 articles to determine ESL teachers' attitudes towards the use of elearning and identify issues faced by ESL teachers in the use of e-learning. E-learning in the teaching of English Language, from the year 2016 until 2020 were collected and only 22 were selected that fit the inclusion criteria. The quantitative method was the most used in previous studies from Table 2, followed by qualitative and mixed methods.

Table 2: Numbers of Study Based on Methods

\begin{tabular}{|l|l|}
\hline Methods & Google Scholar and Eric \\
\hline Quantitative & 14 \\
\hline Qualitative & 6 \\
\hline Mixed-Method & 2 \\
\hline
\end{tabular}


DEVELOPMENT

Vol. 10, No. 1, 2021, E-ISSN: 2226-6348 @ 2021 HRMARS

\section{Findings \& Discussion}

The discussion of each author is represented in Table 3 and 4.

Table 3: Summary of Evidence on the ESL Teachers' Attitudes Towards the Use of E-Learning

\begin{tabular}{|c|c|c|}
\hline No. & Authors & Discussions \\
\hline 1. & $\begin{array}{l}\text { Khoshsima, Saed \& } \\
\text { Arbabi (2018) }\end{array}$ & $\begin{array}{l}\text { The attitudes and approaches of online collaboration among } \\
\text { teachers have been positive towards the online course because } \\
\text { of its uniqueness and positive effects on the learning process. }\end{array}$ \\
\hline 2. & $\begin{array}{l}\text { Dogan \& Akbarov } \\
(2016)\end{array}$ & $\begin{array}{l}\text { Approximately half of the teachers typically use mobile devices } \\
\text { and e-learning materials while teaching; yet another half do not } \\
\text { use devices in their classroom. }\end{array}$ \\
\hline 3. & $\begin{array}{l}\text { Burksaitiene \& } \\
\text { Seleviciene (2017) }\end{array}$ & $\begin{array}{l}\text { Many teachers had optimistic attitudes about the usage of Web } \\
2.0 \text { resources in general and their use in the English language } \\
\text { teaching process. }\end{array}$ \\
\hline 4. & Bauoz (2016) & $\begin{array}{l}\text { The teachers' effort significantly influences the use of social } \\
\text { media, there-fore teachers should be trained on how to } \\
\text { incorporate social media into their instructional activities. }\end{array}$ \\
\hline 5. & $\begin{array}{l}\text { Alahmari \& Kyei- } \\
\text { Blankson (2016) }\end{array}$ & $\begin{array}{l}\text { There is a high level of teacher satisfaction with the use of } \\
\text { Classera with benefits including easy content delivery, } \\
\text { facilitating student learning, and encouraging peer } \\
\text { collaboration and communication between teacher and } \\
\text { parent. }\end{array}$ \\
\hline 6. & Karkoulia (2016) & $\begin{array}{l}\text { Most teachers have positive attitudes towards Web } 2.0 \\
\text { technologies such as YouTube, Google Sites, and blogs to create } \\
\text { a motivating environment. }\end{array}$ \\
\hline 7. & $\begin{array}{l}\text { Semerci \& Aydın } \\
(2018)\end{array}$ & $\begin{array}{l}\text { Teachers have a high degree of positive attitude towards ICT } \\
\text { use in their classrooms, teaching experience, ICT experience, } \\
\text { skills, and training there is no substantial difference in the } \\
\text { willingness of teachers to use ICTs. }\end{array}$ \\
\hline 8. & Mavi \& Ercag (2020) & $\begin{array}{l}\text { Teachers have a positive attitude towards e-learning and } \\
\text { having a high level of e-learning readiness. }\end{array}$ \\
\hline 9. & Alzahrani (2018) & $\begin{array}{l}\text { Most teacher responses in their university and country are } \\
\text { optimistic about e-learning development and e-learning } \\
\text { prospects. }\end{array}$ \\
\hline 10. & Saeheng (2017) & $\begin{array}{l}\text { E-learning and integrated learning will be a successful way of } \\
\text { teaching delivery to enable them to improve their } \\
\text { comprehension of English reading skills and autonomous } \\
\text { learning. }\end{array}$ \\
\hline 11. & Khan (2016) & $\begin{array}{l}\text { This also examines how e-learning can be applied to teachers } \\
\text { and how teachers can obtain help from the e-learning network } \\
\text { by analyzing the research questions conceived for this study. }\end{array}$ \\
\hline
\end{tabular}


Vol. 10, No. 1, 2021, E-ISSN: 2226-6348 @ 2021 HRMARS

\begin{tabular}{|l|l|l|}
\hline 12. & Thamarana (2016) & $\begin{array}{l}\text { E-learning can be described as providing teaching and learning } \\
\text { based on certain pedagogical teaching practices enabled by } \\
\text { technology. }\end{array}$ \\
\hline
\end{tabular}

Table 4: Summary of Evidence on the ESL Teachers' Issues Faced in The Use of E-Learning

\begin{tabular}{|c|c|c|}
\hline No. & Authors & Discussions \\
\hline 1. & $\begin{array}{l}\text { Kibuku, Ochieng \& } \\
\text { Wausi (2020) }\end{array}$ & $\begin{array}{l}\text { The following e-learning challenges rank high in this order: } \\
\text { limited bandwidth, lack of appropriate ICT training, lack of } \\
\text { ICT funding priorities, ICT sustainability, and poverty- } \\
\text { related pressures. }\end{array}$ \\
\hline 2. & $\begin{array}{l}\text { Islam, Beer \& Slack } \\
(2016)\end{array}$ & $\begin{array}{l}\text { The five broad categories are learning style and cultural } \\
\text { challenges, e-learning challenges in terms of pedagogy, } \\
\text { technological challenges, technical preparation challenges, } \\
\text { and challenges in time management. }\end{array}$ \\
\hline 3. & Ajegbelen (2017) & $\begin{array}{l}\text { The challenges were found to be inadequate e-learning } \\
\text { facilities and a lack of regular electricity in Nigeria. }\end{array}$ \\
\hline 4. & $\begin{array}{l}\text { Ahmed, Hussain \& Farid } \\
\text { (2018) }\end{array}$ & $\begin{array}{l}\text { Electricity shortfalls, English language competence, the } \\
\text { non-availability of specialized content, and teacher } \\
\text { dependence are the main issues of e-learning. }\end{array}$ \\
\hline 5. & Kisanga \& Ireson (2016) & $\begin{array}{l}\text { Five major barriers have been identified: poor } \\
\text { infrastructure; financial constraints; inadequate support; } \\
\text { lack of knowledge on e-learning and resistance to change } \\
\text { from teachers. }\end{array}$ \\
\hline 6. & $\begin{array}{l}\text { Kiilu, Nyerere \& Ogeta } \\
\text { (2018) }\end{array}$ & $\begin{array}{l}\text { Recommendations for further investment to be aimed at } \\
\text { providing the necessary e-learning facilities and internet } \\
\text { connectivity to allow teacher trainees to access digital } \\
\text { learning materials, as well as facilitating learner-tutor } \\
\text { collaboration to achieve successful learning. }\end{array}$ \\
\hline 7. & $\begin{array}{l}\text { Grabinski, Kedzior, } \\
\text { Krasodomska \& Herdan } \\
(2020)\end{array}$ & $\begin{array}{l}\text { The factors influencing the effectiveness of e-learning in } \\
\text { teaching accounting include ease of delivery of e-learning, } \\
\text { more regular learning process, a greater degree of } \\
\text { development of social competencies of students during e- } \\
\text { learning classes, and the more efficient process of verifying } \\
\text { the progress of students compared to traditional classes. }\end{array}$ \\
\hline 8. & Obuekwe \& Eze (2017) & $\begin{array}{l}\text { The key problems facing e-learning remain that the } \\
\text { different devices used do not cater for visually disabled } \\
\text { people; unavailability of equipment such as computers, } \\
\text { digital technology, and the internet for cost-effective use; } \\
\text { intermittent energy supply; lack of the technological and } \\
\text { social skills needed to incorporate e-learning. }\end{array}$ \\
\hline 9. & Taat \& Francis (2020) & $\begin{array}{l}\text { Key factors influencing the students' acceptance of e- } \\
\text { learning are usability, characteristics of the lecturer, quality }\end{array}$ \\
\hline
\end{tabular}


Vol. 10, No. 1, 2021, E-ISSN: $2226-6348$ @ 2021 HRMARS

\begin{tabular}{|l|l|l|}
\hline & & $\begin{array}{l}\text { of the system, the information provided, and the technical } \\
\text { support available. }\end{array}$ \\
\hline 10. & $\begin{array}{l}\text { Hadullo, Oboko \& } \\
\text { Omwenga (2018) }\end{array}$ & $\begin{array}{l}\text { The study found that the key factors responsible for } \\
\text { evaluating quality asynchronous e-learning systems were: } \\
\text { course design, material support, course support, social } \\
\text { support, administrative support, learner features, teacher } \\
\text { features, and technician features. }\end{array}$ \\
\hline
\end{tabular}

Previous studies have highlighted discussion to determine ESL teachers' attitudes towards the use of e-learning. The findings of this systematic analysis showed that the optimal level is high when using e-learning in English Language teaching (Mavi \& Ercag, 2020). E-learning offered teachers as well as students a new forum to submit and receive information effectively anywhere and at any time (Khan, 2016). This is because the e-learning process has helped students share ideas, learn and collaborate with their friends through technology and the development of the internet (Bauoz, 2016; Karkoulia, 2016 \& Alzahrani, 2018). Also, the attitudes and approaches of teachers' online collaboration towards online courses were positive due to their uniqueness and positive impact on the learning process. The majority of EFL teachers have optimistic attitudes towards Web 2.0 technology as they use platforms such as YouTube, Google Sites, forums, and wikis to build a motivational learning atmosphere in which both language and life skills are encouraged (Alahmari \& Kyei-Blankson, 2016; Khoshsima, Saed \& Arbabi, 2018; Saeheng, 2017).

However, this study also highlighted issues on and identify issues faced by ESL teachers in the use of e-learning. The following e-learning challenges rank high in this order: limited capacity, lack of adequate ICT preparation, lack of ICT funding priorities, ICT sustainability, and povertyrelated pressures (Kibuku, Ochieng \& Wausi, 2020; Ajegbelen, 2017 \& Ahmed, Hussain \& Farid, 2018). The factors influencing the effectiveness of e-learning in teaching accounting include ease of delivery of e-learning, a more routine learning cycle, a greater degree of development of social competences of students during e-learning classes, and a more productive method of checking the progress of students compared to traditional classes (Grabinski, Kedzior, Kra-sodomska \& Herdan, 2020; Taat \& Francis, 2020). Furthermore, the main challenges faced during e-learning remain that the various technologies used do not provide for visually impaired people; the unavailability of equipment such as computers, digital technology, and the Internet for costeffective use; the irregular supply of electricity; the lack of the technical and social skills required to implement e-learning; (Obuekwe \& Eze, 2017; Hadullo, Oboko \& Omwenga, 2018 \& Kiilu, Nyerere \& Ogeta, 2018).

\section{References}

Hussain, S., \& Farid, S. (2018). Factors Influencing the Adoption of e-Learning in an Open and Distance Learning Institution of Pakistan. Factors Influencing the Adoption of e-Learning in an Open and Distance Learning Institution of Pakistan. The Electronic Journal of e-Learning, 16(2), 148-158.

Burksaitiene, N., \& Seleviciene, E. (2017). University and College Teachers' Attitudes Towards Web 2.0 Technologies and Their Use for Teaching English for General and Specific Purposes. The Journal of Teaching English For Specific and Academic Purposes, 5(2), 
INTERNATIONAL JOURNAL OF ACADEMIC RESEARCH IN PROGRESSIVE EDUCATION AND

DEVELOPMENT

Vol. 10, No. 1, 2021, E-ISSN: 2226-6348 @ 2021 HRMARS

231-240.

Bauoz, T. (2016). Pre-service EFL Teachers' Attitudes towards Language Learning through Social Media. International Conference on Teaching and Learning English as an Additional Language, 14-17.

Dogan, A., \& Akbarov, A. (2016). Teachers' Attitudes toward the Usage of Mobile Devices in EFL Classroom. European Journal of Educational Research, 5(1), 11-17.

Dash, U., \& Barman, P. (2016). Teaching Effectiveness of Secondary School Teachers in the District of Purba Medinipur, West Bengal. IOSR Journal of Humanities and Social Science (IOSR-JHSS). 21(7), 50-63.

Darling-Hammond, L. (2000). Teacher Quality and Student Achievement: A Review of State Policy Evidence. Education Policy Analysis Archive, 8(1), 1068-2341.

Fitriah. (2018). The Role of Technology in Teachers' Creativity Development in English Teaching Practices. TEFLIN Journal, 29(2), 178-193.

Gani, S. A., Fajrina, D., \& Hanifa, R. (2015). Students' learning strategies for developing speaking ability. Studies in English Language and Education, 2(1), 16-28.

Goe, L. (2007). The Link Between Teacher Quality and Student Outcomes: A Research Synthesis. National Comprehensive Centre for Teacher Quality, sponsored under government cooperative agreement number.

Grabinski, K., Kedzior, M., Krasodomska, J., \& Herdan, A. (2020). Embedding E-Learning in Accounting Modules: The Educators' Perspective. Educ. Sci, 10(1), 2-19.

Hardan, A. A. (2013). Language Learning Strategies: A General Overview. Procedia - Social and Behavioral Sciences. Speaking Ability. Studies in English Language and Education Journal, 2(1), 18-30.

Hamid, S. R. A., Hassan, S. S. S., \& Ismail, N. A. H. (2012). Teaching Quality and Performance Among Experienced Teachers in Malaysia. Australian Journal of Teacher Education. 11(5).

Harris, D. N., \& Rutledge, S. A. (2007). Models and Predictors of Teacher Effectiveness: A Review of the Literature with Lessons from (and for) Other Occupations.

Islam, N., Beer, M. D., \& Slack, F. (2016). E-Learning Challenges Faced by Academics in Higher Education: A Literature Review. Journal of Education and Training Studies, 3(5).

Khan, K. S., Kunz, R., Kleijnen, J., \& Antes, G. (2003). Five steps to conducting a systematic review. Journal of the Royal Society of Medicine.

Kiilu, R. M., Nyerere, J. K., \& Ogeta, N. (2018). Teacher-trainee's competency and institutional level of preparedness for adoption of e-learning in selected teacher training colleges in Kenya.

African Educational Research Journal, 6(2), 73-79.

Karkoulia, K. (2016). Teachers' attitudes towards the integration of Web 2.0 tools in EFL teaching. Research Papers in Language Teaching and Learning, 7(1), 46-74.

Khan, I. A. (2016). Effectiveness of E-learning for the Teaching of English: A Study of Comparative Strategies. Advances in Language and Literary Studies, 7(3), 126-135.

Khoshsima, H., Saed, A., \& Arbabi, M. A. (2018). Online Teachers' Attitudes toward Using Technology in Teaching English as a Foreign Language. Journal of Applied Linguistics and Language Research, 5(2), 134-148. 
Kibuku, R. N., Ochieng, D. O., \& Wausi, A. N., 2020. e-Learning Challenges Faced by Universities in Kenya: A Literature Review. The Electronic Journal of e-Learning, 18(2), 150-161.

Kisanga, D. H., \& Ireson, G. (2016). Barriers and strategies on adoption of e-learning in Tanzanian higher learning institutions: Lessons for adopters. International Journal of Education and Development using Information and Communication Technology (IJEDICT), 11(2), 126-137.

Lie, A. (2017). English And Identity in Multicultural Contexts: Issues, Challenges, And Opportunities. TEFLIN Journal, 28(1), 72-92.

Licorish, S. A., George, J.L., Owen, H. E., \& Daniel, B. (2017). “Go Kahoot!” Enriching Classroom Engagement, Motivation and Learning Experience with Games. Proceedings of the 25th International Conference on Computers in Education. New Zealand: Asia-Pacific Society for Computers in Education.

María, A.A., Jorge, B., Jesús, N. M., Javier, S. F., \& José, B. (2018). Results of the use of Kahoot! gamification tool in a course of Chemistry. 4th International Conference on Higher Education Advances (HEAd'18) Universitat Politecnica.

Miangah, T. M., \& Nezarat, A. (2012). Mobile-Assisted Language Learning. International Journal of Distributed and Parallel Systems (IJDPS), 3(1).

Maulidar, K., Gani, S. A., \& Samad, I. A. (2019). Teacher's Strategies in Teaching Speaking For Cadets. English Education Journal (EEJ), 10(1), 80-94.

Mavi, D., \& Ercag, E. (2020). Analysis of the attitudes and the readiness of maker teachers towards e-learning, with use of several variables. International Online Journal of Education and Teaching (IOJET), 7(2), 684-710.

Nadzrah, A. B. (2007). Using Blogs to Develop Interest Among ESL Students: A New Paradigm in Language Education. Paper presented at the 5th Asia TEFL International Conference, Putra World Trade Centre (PWTC), Kuala Lumpur.

Noesgaard S. S., \& Orngreen R. (2015). The Effectiveness of E-Learning: An Explorative and Integrative Review of the Definitions, Methodologies and Factors that Promote eLearning Effectiveness". The Electronic Journal of eLearning, 13(4), 278-290.

Obuekwe, G. I., \& Eze, R. I. (2017). Promoting Best Practices in Teaching and Learning in Nigerian Universities Through Effective E-Learning: Prospects and Challenges. International Conference e-Learning, 184-188.

Pandey, V., \& Mishra, P. B. (2016). Assess the Relationship Between Selfies and Self Esteem Among University Students. IOSR Journal of Humanities and Social Science (IOSRJHSS), 22(12).

Paul, W. (2017). Adjectival modification in Mandarin Chinese and related issues. Linguistics, De Gruyter, 43(4), 757-793.

Rochanahasadin, R., Li, L. K., Sabri, M., \& Pornwasanying, K. (2019). Comparative Study of Language Learning Strategies Used by FirstYear Students at Prince of Songkla University, Pattani Campus, Thailand and UniMAP, Malaysia. Journal of Communication in Scientific Inquiry, 1(1), 1-8.

Saeheng, P. (2017). A Study of e-Learning, Blended learning, and Traditional Teaching Methods to Motivate Autonomous Learning in English Reading Comprehension of Thais Learners. IJELTAL (Indonesian Journal of English Language Teaching and Applied 
INTERNATIONAL JOURNAL OF ACADEMIC RESEARCH IN PROGRESSIVE EDUCATION AND

DEVELOPMENT

Vol. 10, No. 1, 2021, E-ISSN: 2226-6348 @ 2021 HRMARS

Linguistics, 2(1), 1-20.

Semerci, A., \& Aydın, M. K. (2018). Examining High School Teachers' Attitudes towards ICT Use in Education. International Journal of Progressive Education, 14(2), 93-105.

Sintema, E. J. (2020). Effect of COVID-19 on the Performance of Grade 12 Students: Implications for STEM Education. EURASIA Journal of Mathematics, Science and Technology Education, 16(7), 1-6.

Sharma, D. R. (2018). Action Research on Improving Students' Speaking Proficiency in Using Cooperative Storytelling Strategy. Journal of NELTA Surkhet, 5(1), 97-105.

Sikand, D., \& Kauts, A. (2016). Relationship of Teacher Effectiveness, Teacher Stress and Teacher Commitment with Different Dimensions of Creative Management. Scholarly Research Journal for Humanity Science \& English Language, 5(25).

Tehseen, S., \& Hadi, N. (2015). Factors Influencing Teachers' Performance and Retention. Mediterranean Journal of Social Sciences, 6(1).

Thamarana, S. (2016). Role of e-learning and virtual learning environment in English language learning. ELT. International conference.

Taat, M. S., \& Francis, A. (2020). Factors Influencing the Students' Acceptance of E-Learning at Teacher Education Institute: An Exploratory Study in Malaysia. International Journal of Higher Education, 9(1). 133-142.

Teng, F. (2016). The Effects of Word Exposure Frequency on Incidental Learning of the Depth of Vocabulary Knowledge. GEMA Online ${ }^{\circledR}$ Journal of Language Studies, 16(3).

Waxman, C. H., Lin, M. F., \& Michko, G. M. (2003). A Meta-Analysis of The Effectiveness of Teaching and Learning With Technology on Student Outcomes. Naperville, Illinois: Learning Point Associates

Yunus, M. M., Nordin, N., Salehi, H., Embi, M. E. \& Salehi, Z. (2013). The Use of Information and Communication Technology (ICT) in Teaching ESL Writing Skills. English Language Teaching, 6(7), 1916-4750.

Yunus, M. M., Nordin, N., Salehi, H., Sun, H. C., \& Embi, M. A. (2013). Pros and Cons of Using ICT in Teaching ESL Reading and Writing. International Education Studies, 6(7), 1913-9039.

Yunus, M. M., \& Suliman, A. (2014). Information \& Communication Technology (ICT) Tools in Teaching and Learning Literature Component in Malaysian Secondary Schools. Asian Social Science, 10(7), 1911-2017.

Zorío, Z. M. (2018). Using ICTs to boost students' motivation in the EFL classroom.

Zakariaa, M. I., Maat, S. M., \& Khalid, F. (2019). A Systematic Review of M-learning in Formal Education. International Journal of Innovation, Creativity and Change. 7(11), 1-24. 